\title{
Humectants as Post-Plant Soil Amendments: Effects on the Wilting Cycle of Drought-Stressed, Container-Grown Tree Seedlings
}

\author{
Bruce R. Roberts and R. Scott Linder
}

\begin{abstract}
To test the potential effectiveness of humectant-containing compounds for improving soil moisture availability in the rhizosphere of newly transplanted trees, one-year-old Jiffy Plug ${ }^{\mathrm{TM}}$ and bare-root seedlings of red maple (Acer rubrum L.) and red oak (Quercus rubra L.) and one-year-old bare-root seedlings of yellow-poplar (Liriodendron tulipifera L.) were treated with Hydretain ES ${ }^{\mathrm{TM}}$ (HydES) and EcoSential ${ }^{\mathrm{TM}}(\mathrm{EcoS})$ in greenhouse studies. Both products were applied as a root drench to seedlings in $3.8 \mathrm{~L}$ plastic pots containing soilless substrate. Following treatment, water was withheld and days to wilt (DTW) recorded for each seedling. For red maple, HydES at the recommended rate $(16 \mathrm{~mL} / \mathrm{L}, \mathrm{X})$, as well as at $0.75 \mathrm{X}$ and $0.5 \mathrm{X}$, was effective in increasing DTW, as was EcoS at $16 \mathrm{~mL} / \mathrm{L}$ (the recommended rate, X) and at $0.75 \mathrm{X}$. For red oak, the lowest concentration of HydES $(0.5 \mathrm{X})$ was ineffective, but the two higher levels (X and 0.75X) increased DTW significantly when compared to untreated controls. For yellow-poplar, DTW was consistently greater in treated than in untreated seedlings, but the differences were not always statistically significant. The data also indicate that for certain species (e.g. red maple), production type (Jiffy Plug or bare root) may influence the degree to which seedlings respond to humectant treatment.

Key Words. Organic Amendments; Production Type: Red Maple; Red Oak; Root Zone Moisture Management; Yellow-Poplar.
\end{abstract}

The successful establishment of trees after transplanting (postplant) is a major problem facing all segments of the arboricultural industry. Root regeneration is a key factor in determining whether or not a transplant will survive and become established. For root regeneration to be successful, soil moisture in the rhizosphere must be adequate to support new growth. In this regard, post-plant growth and development is likely influenced more by plant-soil-moisture relationships than by any other single factor (Roberts 1986). These relationships are especially critical for trees planted in urban areas where the demand for water resources may exceed existing municipal water supplies, thereby limiting the volume of water available for irrigating newly planted landscape vegetation (St. Hilaire et al. 2008).

To help ameliorate transplant shock and to stimulate postplant growth and development, nontraditional soil additives [defined here as nonfertilizer materials applied to the soil to improve production, vigor, or growth (NCR-103 Committee Report 2004)], have received widespread interest over the past 15-20 years. Included among the numerous backfill soil amendments that have been studied are: composted waste products, humic acid-based root stimulants, hydrophylic gels and mycorrhizal-containing substrates (Kelting et al. 1998; Ferrini and Nicese 2002; Fraser and Percival 2003; Gilman 2004; Abbey and Rathier 2005; Ferrini et al. 2005; Roberts 2006; Chalker-Scott 2007; Scharenbroch 2009). Unfortunately, these amendments are often ineffective, in part because they don't address the issue of post-plant root zone soil moisture stress.

More recent technology has resulted in the development of organic products containing polyhydric alcohols that func- tion as humectants. Humectants are hygroscopic substances containing several hydrophilic groups, often hydroxyl groups, which have a strong affinity to form hydrogen bonds with molecules of water. Aqueous solutions of these organic substances have specific humidity equilibrium points that inhibit evaporation to, and absorb moisture from, the atmosphere at relative humidities above their equilibrium point. Thus, when applied to the growing media around plant material, humectant compounds have the potential of improving the proportion of water available for plant growth by extracting moisture from air spaces within the soil matrix and, in certain instances, by preventing evaporative loss of water out of porous soils.

While humectant-containing compounds have gained widespread acceptance in pharmaceutical formulations, food, and personal care products, their use in agriculture is less well documented. A review of the literature suggests the primary use of humectant materials in agriculture has been as carriers for water-soluble herbicides (Matsumoto et al. 1992; Marzouk et al. 1998; Ramsey et al. 2005; Ramsey et al. 2006). Proprietary products containing humectants also have been used to improve the drought-resistance of bedding plants (Barrett 1991), and to identify transplant production methods that increase establishment rates and yield in tomato (Ciardi et al. 1998). With the exception of an agricultural extension report from Clemson University (Arena 2001), no scientific studies could be found that involve the use of humectant-containing compounds for increasing the drought tolerance of woody plant material.

The objectives of the present project were to determine whether commercially-available humectant-containing products could 
extend the irrigation cycle of recently transplanted, droughtstressed tree seedlings and, if so, at what concentrations were these products effective. The study authors were also interested in whether seedlings representing different production types might respond differently to humectant treatment. Finally, the authors wanted to ascertain whether humectant treatment might alter growth and/or physiological activity, thereby having a potential long term impact on transplant survival. The results of these latter investigations will be the subject of a subsequent research report.

All of the studies reported here were conducted in a greenhouse using plant material grown in a soilless substrate to help eliminate some of the environmental variables that often confound the results obtained with field trials. Seedling material was used as an important first step before attempts were made to evaluate the effectiveness of these techniques using larger plant material under field conditions.

\section{METHODS AND MATERIALS}

\section{Study}

One-year-old seedlings of both Jiffy Plug ${ }^{\mathrm{TM}}$ (seeded and grown in a peat pellet encased in biodegradable mesh) and bare root (seeded and grown in soil) red maple (Acer rubrum L.) and red oak (Quercus rubra L.) were purchased from Vans Pines Nursery, West Olive, Michigan, U.S. In mid-February, fifty $15-30 \mathrm{~cm}$ tall Jiffy Plug and fifty $15-30 \mathrm{~cm}$ tall bare-root seedlings of both species were transplanted into $3.8 \mathrm{~L}$ plastic pots containing a soilless substrate consisting of composted pine bark, coconut pith coir, sphagnum peat moss, processed bark ash, and perlite (Metromix 560; Sun Gro Horticulture, Vancouver, BC, Canada). The chemical and physical properties of this substrate have been reported elsewhere (Roberts 2006).

At planting, the root systems of Jiffy Plug seedlings were left undisturbed (unpruned) while those of bare-root seedlings were pruned back $25 \%-35 \%$ to facilitate placement in the planting container. To distinguish between seedlings representing the two production methods used in these studies, the term "production type" is introduced here and is used hereafter to differentiate between plant material seeded and grown in a peat plug and having an intact, unpruned root system (PPS), versus plant material seeded and grown in soil and having a bare-root, root-pruned root system (BRS).

After planting, seedlings were placed in the greenhouse $\left(18^{\circ} \mathrm{C}-26^{\circ} \mathrm{C} ; 60+/-12 \%\right.$ relative humidity) and exposed to 10 hours of light [80-120 W/m² photosynthetically active radiation (PAR; natural day length plus supplemental illumination from 175-W metal halide lamps on a two-hour photoperiod)]. At the end of March, after new foliage had formed, 24 seedlings of each species (red maple; red oak) and each production type (PPS; BRS), a total of 96 seedlings, were selected for treatment. To ensure uniformity in size, seedlings were selected based on comparable growth index measurements (height plus two-dimensional crown width; Monterusso et al. 2005). Treatment consisted of soil drench applications of Hydretain ES ${ }^{\mathrm{TM}}$ (HydES), a commercially available liquid product containing a patented blend of humectant and hygroscopic compounds (Ecologel Solutions LLC, Ocala, FL, U.S.). Six seedlings of each species and each production type were assigned to one of the following four treatments: (1) no chemical; (2) HydES at the recommended rate, X, (16 mL/L); (3) HydES at half the recommended rate, $0.5 \mathrm{X}$; or (4) HydES at twice the recommended rate, $2 X$. Up until the time of treatment, all seedlings were hand-watered as needed to maintain media moisture content at field capacity. Approximately one week prior to treatment, seedlings were fertilized with both Osmocote Plus 15-9-12 controlled release fertilizer (15 g/pot) and Micromax granular micronutrient fertilizer (2.5 g/pot), both applied as a top dressing (Scotts-Sierra Horticultural Products Co., Marysville, OH, U.S.). At the time of treatment, $350 \mathrm{~mL}$ of either water (treatment 1) or HydES (treatments 2-4) was applied to each container as a root drench. This amount of liquid was sufficient to thoroughly wet the substrate in each container. A $15-\mathrm{cm}$ diameter plastic tray was placed beneath each container to collect any excess liquid and to allow for subsequent re-absorption.

Seedlings were placed on a greenhouse bench and, starting the day after treatment, a progressive drought cycle was imposed by withholding water. The number of days until the appearance of foliar wilt (DTW) was then recorded for each seedling. For this investigation, DTW was determined by the appearance of one or more of the following foliar symptoms: angle of petiole to stem $>90^{\circ}$; angle of leaf blade to petiole $>90^{\circ}$; angle of leaf blade to mid-rib $>180^{\circ}$.

\section{Study}

Based on the results of the 2007 investigation, an additional greenhouse study was initiated in 2008 using PPS and BRS red maple seedlings similar to those used in 2007 along with 45-60 $\mathrm{cm}$ tall bare-root seedlings(BRS) of yellow-poplar (Liriodendron tulipifera L.). HydES was again used as one of the humectants as was a similar product, EcoSential ${ }^{\mathrm{TM}}$ (LESCO, Inc., Cleveland, OH, U.S.). EcoSential ${ }^{\mathrm{TM}}$ (EcoS) differs from HydES in that the humectant-containing component of the product is slightly lower while the non-ionic surfactant component is appreciably higher, a condition which should facilitate greater soil penetration.

Plant material (50 each of PPS and BRS red maples and 50 BRS yellow-poplars) was received from the nursery in midFebruary, potted in $3.8 \mathrm{~L}$ plastic containers in soilless substrate and placed in the greenhouse as described previously. By midApril the red maples had produced new foliage and were ready for treatment. Using growth index as a method for determining uniformity in size, 35 seedlings of each production type (PPS and BRS) were selected for treatment, seven replications per treatment, a total of 70 seedlings. Treatments $(350 \mathrm{~mL}$ root drench per container) consisted of: (1) no chemical; (2) HydES at the recommended rate, $\mathrm{X}(16 \mathrm{~mL} / \mathrm{L})$; (3) HydES at $0.75 \mathrm{X}(12 \mathrm{~mL} / \mathrm{L})$; (4) EcoS at the recommended rate, $\mathrm{X}(16 \mathrm{~mL} / \mathrm{L})$; or (5) EcoS at $0.75 \mathrm{X}$. As in the 2007 study, all seedlings were hand-watered as needed up until the time of treatment and were fertilized once prior to treatment with a combination of both controlled release and micronutrient fertilizers as previously mentioned.

To obtain information on media moisture content during the dry down period, daily moisture readings were taken on one set of seedlings (the PPS red maples) using a moisture meter (HH2) and sensor (SM200) (Delta-T Devices, Ltd., Cambridge, UK).

Approximately three weeks after the red maples were treated, the yellow-poplars had broken dormancy and were ready for treatment. The same five treatments $(0 ; \mathrm{X}$ and $0.75 \mathrm{X}$ HydES; $\mathrm{X}$ and $0.75 \mathrm{XEcoS}$ ) were used in treating 35 poplars, seven replications per treatment, $350 \mathrm{~mL}$ drench per container, once again using growth index as the criterion for determining uniformity in seedling size between treatments. As in 2007, initiation of a progressive drought 
cycle was started the day after treatment, and DTW was recorded for each seedling using the methodology previously described.

DTW data from both the 2007 and 2008 trials were analyzed as randomized complete block designs using an analysis of variance (ANOVA). Because there were no PPS yellow-poplar seedlings available, the design is unbalanced for the 2008 trials. For each year, the study authors fit an ANOVA model containing all significant and estimable main effects and interactions. For the 2007 trials, treatment, species (red maple; red oak), production type (PPS; BRS), and the interaction between species and production type, were included in the model. For the 2008 trials, only the main effects were both estimable and significant. Models were fit and analyzed using the statistical software packages Minitab (version 15; State College, PA, U.S.) and R.

Differences in treatment means were compared using Tukey's pairwise comparisontestat significancelevels of 0.01 to 0.05. Graphic analyses of the data were prepared as side-by-side box plots (Moore and McCabe 2002) where each box bisected by a line represents the median value bounded by both upper and lower quartiles. Vertical lines at the top and bottom of each box indicate the range of data and illustrate important differences that exist between treatments. Box plots provide a graphical comparison of groups of numbers, and are used to visually compare "within treatment variation" with "between treatment variation" in a manner analogous to ANOVA.

\section{RESULTS AND DISCUSSION}

In analyzing the data for the 2007 trials, it was revealed the estimated increase in DTW for both species (red maple and red oak) and both production types (PPS and BRS) was 9.2 days for HydES applied at the recommended rate $(16 \mathrm{~mL} / \mathrm{L})$ and 10 days for HydES applied at twice the recommended rate (Figure 1$)$. Both values were highly significant $(P<0.01)$. These results show that doubling the application rate of HydES has little impact on DTW (9.2 versus 10 days), and is probably not cost effective under most circumstances. HydES applied at a concentration of $8 \mathrm{~mL} / \mathrm{L}$ (half the recommended rate) was only marginally effective, increasing DTW by 3.9 days $(P<0.05)$. Overall, the results of the 2007 trials indicate that HydES can be

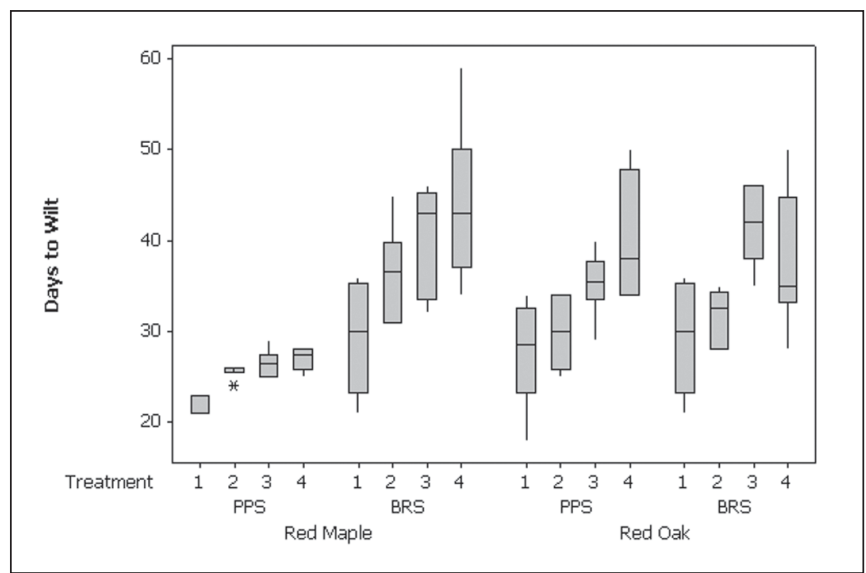

Figure 1. The effect of media-applied humectant [Hydretain ES (HydES)] on number of days to wilt (DTW) of one-year-old drought-stressed red maple and red oak seedlings representing different production types [peat plug system (PPS); bare-root system (BRS)]. Treatments 1: no chemical; 2: HydES at $8 \mathrm{~mL} / \mathrm{L}$ (0.5X); 3: HydES at $16 \mathrm{~mL} / \mathrm{L}(X)$; and 4: HydES at $32 \mathrm{~mL} / \mathrm{L}(2 \mathrm{X})$. an effective product for extending the irrigation cycle of drought stressed red maple and red oak seedlings when applied as a soil drench at the manufacturer's recommended rate $(16 \mathrm{~mL} / \mathrm{L})$.

Data for the 2008 trials (Figure 2) illustrate treatment with either HydES or EcoS successfully extended DTW for humectant-treated seedlings of both PPS and BRS red maples and BRS yellow-poplars. Compared to the untreated controls, the estimated increase in DTW was 8.6 days $(P<0.01)$ for HydES applied at the recommended rate $(\mathrm{X})$, and 4.7 days $(P<0.05)$ for HydES applied at a rate of $0.75 X$. For EcoS, the estimated increase in DTW was 8.1 days $(P<0.01)$ for humectanttreated seedlings at the recommended rate $(\mathrm{X})$, and 6.5 days $(P<0.05)$ at a concentration of $0.75 \mathrm{X}$. These results indicate both humectants, when applied in the range of $12-16 \mathrm{~mL} / \mathrm{L}$, can extend DTW for treated, drought stressed seedlings of red maple and yellow-poplar. The results of these trials also indicate there were no appreciable differences in the effectiveness of the two products at the concentrations used in these studies.

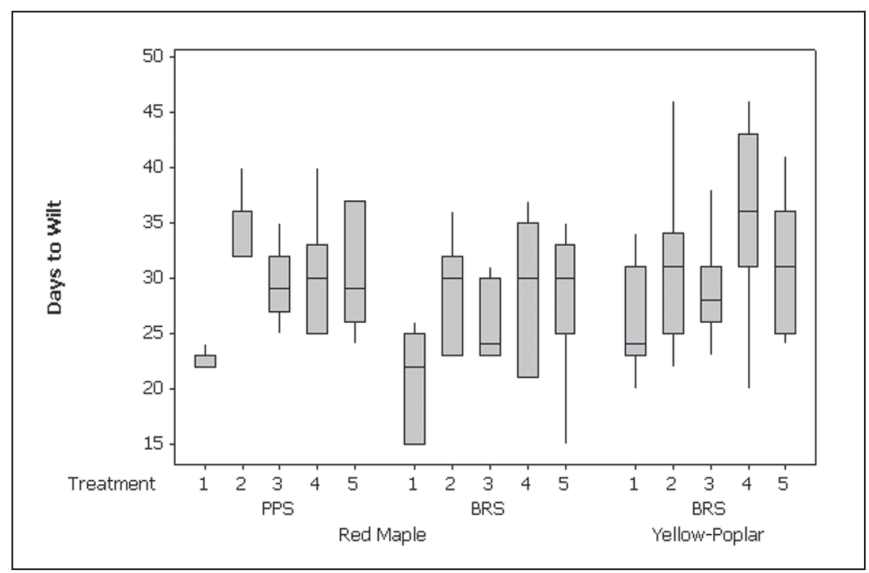

Figure 2. The effect of two media-applied humectants [Hydretain ES (HydES) and EcoSential (EcoS)] on number of days to wilt of one-year-old drought-stressed red maple and yellow-poplar seedlings representing different production types [peat plug system (PPS); bare-root system (BRS)]. Treatments 1: no chemical; 2: HydES at $16 \mathrm{~mL} / \mathrm{L}(\mathrm{X})$; 3: HydES at $12 \mathrm{~mL} / \mathrm{L}(0.75 \mathrm{X})$; 4: EcoS at $16 \mathrm{~mL} / \mathrm{L}(\mathrm{X})$; and 5: EcoS at $12 \mathrm{~mL} / \mathrm{L}(0.75 \mathrm{X})$.

Altering root ball shape can have a dramatic effect on root growth potential (Struve et al. 1989), and as a result, on the ability of a plant to absorb moisture from the soil. Table 1 compares DTW for humectant-treated seedlings representing the two production types found in these studies. In 2007, the number of days to wilt was significantly greater for BRS maples than for PPS maples at all concentrations of HydES tested. And, in similar trials conducted the same year, BRS oaks treated with HydES at $16 \mathrm{~mL} / \mathrm{L}$ (the recommended rate) also showed significantly higher DTW values than did comparably treated PPS oaks. These data suggest BRS seedlings of red maple and red oak may be somewhat more responsive to humectant treatment than are comparable sized PPS seedlings of the same species, but additional studies are needed to confirm these observations.

Daily media moisture readings taken on PPS maples during the 2008 experiments show that, starting the first week after treatment and continuing for the duration of the drought cycle, the moisture content in humectant-treated substrate was 
always greater than it was in untreated substrate (Table 2). While soil moisture was undetectable $(0 \%)$ in untreated substrate after three weeks without water, measurable quantities of water were still present in humectant-treated substrate six weeks after the drought cycle began. These findings suggest humectant treatment is likely to have a greater impact on soil moisture content than on the water potential of the roots themselves.

In one of only a few published studies involving the use of humectants as root zone moisture-managing chemicals, media-applied Hydretain ${ }^{\mathrm{TM}}$ (an earlier proprietary product similar to HydES but containing 20\% less humectant), was found to delay the onset of foliar wilt in a variety of bedding plants when applied at dilution rates ranging from 1:5 to 1:20 (Barrett 1991). And, using the same product, Ciardi et al. (1998) reported that the addition of Hydretain applied as a root drench at a concentration of $6.7 \%$ significantly increased the yield of tomato transplants. In the only study involving woody plant material, Arena (2001) reported that Hydretain (13 mL/L) applied to container-grown live oaks receiving one-third less irrigation resulted in caliper growth $39 \%$ greater than similar untreated oaks receiving the same reduced irrigation schedule.

While the studies reported here were designed to test the effectiveness of soil-applied humectants in ameliorating transplant stress, another strategy to enhance post-plant establishment involves the use of antitranspirant sprays. These products (wax, latex, or acrylic emulsions) characteristically have a low permeability to water vapor, and are sprayed on leaf surfaces to decrease transpirational water loss and improve plant-water status (Goreta et al. 2007). Scientific literature on antitranspirant sprays is robust, but the results are quite varied and generally inconclusive. Plaut et al. (2004) reported that the magnitude of the response to antitranspirant sprays tends to be highly species or cultivar dependent.

In summarizing the results of these present greenhouse studies with media-applied humectants, it is concluded that both products (HydES and EcoS) exhibit the potential for extending DTW of newly planted, drought-stressed seedlings of red maple, red oak, and, to a lesser degree, yellow-poplar. Overall, treatment at the recommended rate $(16 \mathrm{~mL} / \mathrm{L})$ resulted in the most consistent response but, in some instances, concentrations less than the recommended rate were also effective. While there was evidence to suggest that production type had an impact on the effectiveness of humectant treatment, further research is needed to confirm these observations. Based on the results of these investigations, additional studies using larger sized plant materials seem warranted in order to determine the potential usefulness of these products under field conditions.

Acknowledgments. This project was carried out with financial support from the TREE Fund's Hyland Johns research grant program (06-HJ-06). The authors acknowledge technical assistance provided by Dan Krofcheck and Evan Wainright.
Table 1. Comparison of DTW for one-year-old droughtstressed, humectant-treated red maple and red oak seedlings representing different production types ${ }^{2}$.

\begin{tabular}{|c|c|c|c|c|c|c|}
\hline \multirow[t]{2}{*}{ Year } & \multirow[t]{2}{*}{ Species } & \multirow[t]{2}{*}{ Humectant ${ }^{\mathrm{y}}$} & \multirow{2}{*}{$\begin{array}{l}\text { Concn } \\
(\mathrm{mL} / \mathrm{L})\end{array}$} & \multicolumn{2}{|c|}{ DTW $^{x}$} & \multirow[t]{2}{*}{$P$-value } \\
\hline & & & & PPS $^{w}$ & $\mathrm{BRS}^{\mathrm{v}}$ & \\
\hline \multirow[t]{6}{*}{2007} & Red & HydES & 8 & 25.7 & 36.3 & $0.00 * *$ \\
\hline & maple & & 16 & 26.5 & 40.4 & $0.00 * *$ \\
\hline & & & 32 & 27.0 & 44.0 & $0.00 * *$ \\
\hline & Red & HydES & 8 & 29.8 & 31.7 & 0.39 \\
\hline & oak & & 16 & 35.3 & 41.7 & $0.02 *$ \\
\hline & & & 32 & 40.2 & 37.7 & 0.57 \\
\hline \multirow[t]{4}{*}{2008} & Red & HydES & 12 & 29.3 & 25.6 & 0.06 \\
\hline & maple & & 16 & 35.4 & 28.1 & $0.01 * *$ \\
\hline & Red & EcoS & 12 & 30.0 & 27.9 & 0.52 \\
\hline & maple & & 16 & 30.4 & 28.1 & 0.52 \\
\hline
\end{tabular}

${ }^{\mathrm{z}}$ One-year-old seedlings grown in a greenhouse in $3.8 \mathrm{~L}$ plastic containers filled with soilless substrate. Each value represents the mean of six (2007) or seven (2008) replications. Comparisons between production types for each species and each level of humectant made using Tukey's pairwise comparison test, $P<0.05$ (*), $P<0.01$ (**).

${ }^{y}$ Humectant applied as a media drench at $350 \mathrm{~mL}$ per container.

${ }^{x}$ Number of days to wilt.

${ }^{\text {w }}$ Peat plug system.

${ }^{v}$ Bare-root system.

Table 2. The effect of drought on the moisture content of humectant-treated soilless substrate (Metromix 560) planted with one-year-old Jiffy Plug red maple seedlings ${ }^{2}$.

\begin{tabular}{llllll}
\hline \multirow{2}{*}{$\begin{array}{l}\text { Drought } \\
\text { period (wks) }\end{array}$} & \multirow{2}{*}{$\begin{array}{l}\text { No } \\
\text { humectant }\end{array}$} & \multicolumn{2}{c}{ Hydretain ES } & \multicolumn{2}{c}{ EcoSential } \\
\cline { 2 - 6 } & 56.6 & 64.8 & 57.5 & 56.8 & 67.5 \\
1 & 30.1 & 31.6 & 33.7 & 34.4 & 38.7 \\
2 & 14.0 & 24.6 & 20.6 & 21.7 & 26.8 \\
3 & 0 & 13.1 & 9.2 & 12.4 & 10.9 \\
4 & 0 & 7.6 & 2.5 & 3.6 & 5.5 \\
5 & 0 & 1.1 & 0.4 & 2.0 & 1.6 \\
6 & &
\end{tabular}

${ }^{\mathrm{z}}$ Moisture content expressed as percent saturation. Humectants applied as a root drench $(350 \mathrm{~mL})$ prior to initiation of a progressive drought cycle. Seedlings grown in the greenhouse in $3.8 \mathrm{~L}$ plastic pots (2008 trials). Each value represents the mean of seven replications. 


\section{LITERATURE CITED}

Abbey, T., and T. Rathier. 2005. Effects of mycorrhizal fungi, biostimulants and water absorbing polymers on the growth and survival of four landscape plant species. Journal of Environmental Horticulture 23:108-111.

Arena, M.J. 2001. Evaluation of Hydretain 2X on container grown trees. Clemson Univ. Extension Service. <www.hydretain.com/literature/ container_grown_trees.pdf>

Barrett, J. 1991. New media-applied humectant can improve plants' drought resistance. Greenhouse Manager 10:123.

Chalker-Scott, L. 2007. Impact of mulches on landscape plants and the environment - a review. Journal of Environmental Horticulture 25:239-249.

Ciardi, J.A., C.S. Vavrina, and M.D. Orzolek. 1998. Evaluation of tomato transplant production methods for improving establishment rates. HortScience 33:229-232.

Ferrini, F., and F.P. Nicese. 2002. Response of English oak (Quercus robur $\mathrm{L}$.) trees to biostimulants application in the urban environment. Journal of Arboriculture 28:70-75.

Ferrini, F., A. Giuntoli, F.P. Nicese, S. Pelligrini, and N. Vignozzi. 2005. Effect of fertilization and backfill amendments on soil characteristics, growth and leaf gas exchange of English oak (Quercus robur L.). Journal of Arboriculture 31:182-190.

Fraser, G.A., and G.C. Percival. 2003. The influence of biostimulants on growth and vitality of three urban tree species following transplanting. Arboricultural Journal 27:43-57.

Gilman, E.F. 2004. Effects of amendments, soil additives, and irrigation on tree survival and growth. Journal of Arboriculture 30:301-305.

Goreta, S., D.I. Leskovar, and J.L. Jifon. 2007. Gas exchange, water status, and growth of pepper seedlings exposed to transient water deficit stress are differentially altered by antiranspirants. Journal of the American Society for Horticultural Science 132:603-610.

Kelting, M., J.R. Harris, J. Fanelli, and B. Appleton. 1998. Biostimulants and soil amendments affect two-year posttransplant growth of red maple and Washington hawthorne. HortScience 33:819-822.

Marzouk, H., P. Baur, and J. Schonherr. 1998. Relative solubilities of bifenox and 1-naphthylacetic acid (NAA) in plant cuticles and in selected pure or aqueous glycol additives. Pesticide Science 53: 278-284.

Matsumoto, S., S. Suzuki, H. Tomita and T. Shigematsu. 1992. Effect of humectants on pesticide uptake through plant leaf surfaces, pp. 261-271. In: C.L. Foy (Ed.). Adjuvants for Agrochemicals. CRC Press, Boca Raton, FL.

Monterusso, M.A., D.B. Rowe, and C.L. Rugh. 2005. Establishment and persistence of Sedum spp. and native taxa for green roof applications. HortScience 40:391-396.
Moore, D.S., and G.P. McCabe. 2002. Introduction to the Practice of Statistics, 4th Edition. W.H. Freeman \& Co., New York, NY.

NCR-103 Committee Report. 2004. Nonconventional soil additives: Products, companies, ingredients and claims. <www.soils.wisc.edu/ extension/hottopics/2004nonconventional.htm>

Plaut, Z., Y. Magril, and U. Kedem. 2004. A new film forming material which reduces water vapour conductance more than $\mathrm{CO}_{2}$ fixation in several horticultural crops. Journal of Horticultural Science and Biotechnology 79:528-532.

Ramsey, R.J.L., G.R. Stephenson, and J.C. Hall 2005. A review of the effects of humidity, humectants and surfactant composition on the absorption and efficacy of highly water-soluble herbicides. Pesticide Biochemistry and Physiology 82:162-175.

Ramsey, R.J.L., G.R. Stephenson, and J.C. Hall. 2006. Effect of humectants on the uptake and efficacy of glufosinate in wild oat (Avena fatua) plants and isolated cuticles under dry conditions. Weed Science 54:205-211.

Roberts, B.R. 1986. Methods for measuring water status and reducing transpirational water loss in trees. Journal of Arboriculture 13:56-61.

Roberts, B.R. 2006. Compost-containing substrates and their effect on post- transplant growth of containerized tree seedlings. Arboriculture \& Urban Forestry 32:289-296.

Scharenbroch, B.C. 2009. A meta-analysis of studies published in Arboriculture \& Urban Forestry relating to organic materials and impacts on soil, tree, and environmental properties. Arboriculture \& Urban Forestry 35:221-231.

St. Hilaire, R., M.A. Arnold, D.C. Wilkerson, D.A. Devitt, B.H. Hurd, B.J. Lesikar, V.I. Lohr, C.A. Martin, G.V. McDonald, R.L. Morris, D.R. Pittenger, D.A Shaw, and D.F. Zoldoske. 2008. Efficient water use in residential urban landscapes. HortScience 43:2081-2092.

Struve, D.K., T.D. Sydnor, and R. Rideout. 1989. Root system configuration affects transplanting of honeylocust and English oak. Journal of Arboriculture 15:129-134.

Bruce R. Roberts (corresponding author)

Dept. of Botany \& Microbiology

Ohio Wesleyan University

Delaware, OH 43015, U.S.

broberts@owu.edu

R. Scott Linder

Dept. of Mathematics and Computer Science

Ohio Wesleyan University

Delaware, OH 43015, U.S. 
Résumé. Afin de tester l'efficacité potentielle des composés à contenu humectant pour améliorer l'humidité disponible dans le sol pour la rhizosphère des arbres nouvellement plantés, des semis d'un an d'érable rouge (Acer rubrum L.) et de chêne rouge (Quercus rubra L.) produits avec des Jiffy PlugTM et à racines nues ainsi que des semis d'un an à racines nues de tulipier de Virginie (Liriodendron tulipifera $\mathrm{L}$.) ont été traités avec le Hydretain ES ${ }^{\mathrm{TM}}$ (HydES) et le EcoSential (EcoS) dans le cadre d'une étude en serre. Les deux produits ont été appliqués par trempage des racines des semis dans des pots en plastique de $3,8 \mathrm{~L}$ qui contenaient un substrat sans sol. Après le traitement, l'eau a été retenue et le nombre de jours pour l'atteinte du point de flétrissement enregistré pour chacun des semis. Pour l'érable rouge, le HydES au taux recommandé ( $16 \mathrm{~mL} / \mathrm{L}$, $1 \times$ ), tout comme aux taux de $0,75 \times$ et de $0,5 \times$, s'est avéré efficace pour accroître le délai jusqu'au point de flétrissement, tout comme l'a été le EcoS au taux de $16 \mathrm{~mL} / \mathrm{L}$ (le taux recommandé de $1 \times$ ) et à $0,75 \times$. Pour le chêne rouge, le plus faible taux de concentration de HydES $(0,5 \times)$ s'est avéré inefficace, mais les deux concentrations plus élevées $(1 \times$ et $0,75 \times$ ) ont permis d'accroître significativement le délai avant l'atteinte du flétrissement comparativement aux arbres-témoin. Pour le tulipier de Virginie, l'atteinte du délai avant le flétrissement était considérablement plus élevé chez les semis traités que ceux du groupe-témoin non traités, mais les différences n'étaient pas toujours statistiquement significatives. Les données ont aussi indiquées que pour certaines espèces (ex.: érable rouge), le type de production (Jiffy Plug ou à racines nues) pouvait avoir une influence par rapport au degré avec lequel les semis répondaient au traitement d'humectation.

Zusammenfassung. Um die potentielle Effektivität von feuchtigkeitsspendenen Bestandteilen zur Verbesserung der Bodenfeuchteverfügbarkeit in der Rhizosphäre Frisch verpflanzter Bäume, einjährige Sämlinge in Jiffy-Behältern und nacktwurzelige Sämlinge von Rotahorn und Roteiche, sowie einjährige, nacktwurzelige Sämlinge von Tulpenbäumen zu messen, wurden in Gewächshausstudien Hydretain und EcoSential appliziert. Beide Produkte wurden auf den Wurzelteller der Sämlinge in 3,8 1 Plastikcontainern mit bodenfreiem Substrat aufgebracht. Nach der Behan- dlung wurde nicht mehr gewässert und die Tage bis zur Welke für jeden Sämling notiert. Hydretain, in der empfohlenen Gabe von $16 \mathrm{~mL} / \mathrm{L}$, X wie auch bei $0,75 \mathrm{X}$ und $0,5 \mathrm{X}$, verlängerte den Zeitraum bis zur Welke, das galt auch für EcoSential in der empfohlenen Gabe von $16 \mathrm{~mL} / \mathrm{L}$ (die Empfehlung, X) und bei 0,75X. Bei der Roteiche war die niedrigste Konzentration von Hydretain $(0,5 \mathrm{X})$ uneffektiv, aber die zwei höheren Level (X und 0,75X) verlängerten den Zeitraum bis zur Welke deutlich im Vergleich zur ungehandelten Kontrolle. Beim Tulpenbaum war der Zeitraum bis zur Welke anhaltend größer als bei den unbehandelten Sämlingen, aber die Unterschiede waren nicht immer statistisch relevant. Die Daten zeigen auch daß für bestimmte Arten (z. B. Rotahorn) der Produktionstyp (z. B. Jiffy-Topf oder Nacktwurzler) auch einen Einfluss auf die Wirksamkeit von feuchtigkeitsspendenden Zusatzstoffen hat.

Resumen. Para probar la efectividad potencial de compuestos con contenido de humectantes para mejorar la disponibilidad de humedad en la rizosfera de árboles recientemente trasplantados fueron tratados árboles de un año a raíz desnuda de maples Jiffy Plug ${ }^{\mathrm{TM}}$ (Acer rubrum L.), encino rojo (Quercus rubra L.) y álamos amarillos (Liriodendron tulipifera $\mathrm{L}$.) fueron tratados con Hydretain $\mathrm{ES}^{\mathrm{TM}}$ (HydES) y EcoSential ${ }^{\mathrm{TM}}$ (EcoS) en estudios de invernadero. Ambos productos fueron aplicados en zanjas a los brinzales en envases plásticos de $3.8 \mathrm{~L}$ conteniendo substrato sin suelo. Después de los tratamientos, el agua fue suspendida hasta el marchitamiento (DTW) registrado para cada brinzal. Para maple rojo, HydES a la tasa recomendada $(16 \mathrm{~mL} / \mathrm{L}, \mathrm{X})$, así como a $0.75 \mathrm{X}$ y $0.5 \mathrm{X}$, fue efectiva en incrementar DTW, como fue EcoS a $16 \mathrm{~mL} / \mathrm{L}$ (la tasa recomendada, $\mathrm{X}$ ) y a $0.75 \mathrm{X}$ y $0.5 \mathrm{X}$. Para encino rojo, la concentración más abaja de HydES (0.5X) no fue efectiva, pero los dos niveles más altos (X y $0.75 \mathrm{X}$ ) incrementaron DTW significativamente cuando se compararon con controles no tratados. Para los álamos amarillos, DTW fue consistentemente mayor en brinzales tratados que en no tratados, pero las diferencias no siempre fueron estadísticamente significativas. Los datos también indican que para ciertas especies (como el maple rojo), tipo de producción (Jiffy Plug o raíz desnuda) puede influir el grado al cual los brinzales responden a los tratamientos humectantes. 